\title{
Migration and circulation as a way of life for the Wosera Abelam of Papua New Guinea
}

\author{
George Curry and Gina Koczberski
}

\begin{abstract}
Migration and circulation are now an integral part of the socio-economy of the Wosera Abelam of Papua New Guinea. Since the 1950s large numbers of Wosera Abelam have settled in West New Britain (WNB) towns and government sponsored resettlement schemes. These long-term migrants provide a base in WNB for temporary migrants from the Wosera seeking work or a break from village life. This paper explores the linkages between temporary and long-term migrants in WNB, and between migrants and their relatives remaining in the village. We argue that migration is now a 'way of life' for the Wosera Abelam, and is, to a large extent, underpinned by indigenous (precapitalist) social and economic relations.
\end{abstract}

Keywords: migration, Papua New Guinea, indigenous exchange, development

Approximately 15 percent of the Wosera population in the East Sepik Province, Papua New Guinea, is living elsewhere in the country (PNGIMR, 1986), many of them being short-term absentees away for periods of up to three years. In an area such as the Wosera where migration rates are so high, it is of interest to explore how migration has been socially constructed by the Wosera Abelam, a people whose economic and socio-cultural forms have proved remarkably robust despite capitalist penetration. The paper reports on the dynamic two-way interactions between migration to West New Britain Province (an expression of the introduced capitalist economy), and indigenous (precapitalist) economic and cultural forms. ${ }^{1}$ It is argued that contemporary migration for the Wosera involves a complex interaction between these two socio-economic frameworks such that the ostensibly modern and capitalist phenomenon of long-distance migration is imbued with meanings and values that are 'pre-modern' and non-market in form. Contemporary patterns of Wosera migration do not reflect the transformation of Wosera society, but

Authors: George Curry and Gina Koczberski, School of Social Sciences and Asian Languages, Curtin University, GPO Box U1987, Perth, Western Australia 6001. E-mail: gcurry@spectrum.curtin.edu.au 
rather a process of 'hybridisation' in which events, processes and objects draw simultaneously on both indigenous and capitalist socio-economies for their values and meanings. Whilst we acknowledge that uneven spatial development, land shortages and inequalities in resource access are relevant to explaining migration, we argue that contemporary migration patterns constitute a negotiated response to capitalist penetration in which migration behaviour both structures, and is structured by, indigenous socio-economic relationships and cultural values.

\section{THE LITERATURE}

Until recently most migration research was located within one of two broad theoretical frameworks: functionalist approaches, like neo-classical economics; and structuralist approaches, such as some neo-Marxist and dependency theories. The former framework employs 'push-pull' quantitative models of decision-making behaviour usually emphasising the demographic and economic characteristics of migration (for a review see Massey et al., 1993; Goss and Lindquist, 1995; Moon, 1995; see also Gardner, 1995). These models employ notions of economically rational decision-makers, with migration being interpreted as a response to spatial variations in income opportunities. The neo-classical view, with its focus on the individual, ignores the social relations of production and reproduction in favour of utility maximisation. This assumes individuals have alienable rights over things that they own and are able to enter transactions where they can make decisions unfettered by ties and obligations, such as those formed by kinship in clan-based societies. Migration is thus viewed as the outcome of decision-making by the autonomous individual and is conceptualised as a mechanism of 'trickle-down' which can be statistically modelled as flows of people and income through space and time. As an explanatory model it is too narrow because it is confined to economics and demography, thus ignoring the social and cultural dimensions of migration.

During the 1980s the 'New Economics of Migration' (NEM) emerged to address some of the weaknesses of neo-classical theory, particularly the notion of the individual decision-maker (Stark and Bloom, 1985). NEM uses 'larger units of related people - typically families or households - in which people act collectively not only to maximise expected income, but also to minimise risks and to loosen constraints associated with a variety of market failures ...' (Massey et al., 1993: 436). NEM is an improvement on the neo-classical perspective, but it remains constrained by concepts and assumptions drawn from the market economy. For example, migration is interpreted as a response to 'failures' in the markets for futures, crop insurance and capital, thereby rendering the precapitalist economy largely invisible. Therefore, NEM can offer only a partial perspective on migrant decision-making in societies that retain strong precapitalist social and economic relations.

Structural interpretations like dependency theory, world systems theory and modes of production view labour migration as a mechanism for accumulation where labour in the periphery is exploited by capitalist imperialism, originally 
through slavery, and in the colonial and postcolonial periods, as indentured migrant labour driven by compulsive economic forces (Wolpe, 1972; Amin, 1974; Wallerstein, 1974; Burawoy, 1976; Curtain, 1981; Meillassoux, 1981; for an overview see Massey et al., 1993; Goss and Lindquist, 1995). These structural interpretations are deterministic in the sense that it was believed that precapitalist society would either be transformed, or preserved as an underdeveloped, dependent and passive vestige of its former state to provide a labour subsidy for capitalism. But in PNG, for example, the penetration of global capitalism has not produced a one-way transformation of rural society (cf, Rowley, 1965; Epstein, 1968; Finney, 1973), nor has incorporation produced a stagnant, unchanging and dependent indigenous sector (cf, Wolpe, 1980; Fitzpatrick, 1980; Meillassoux, 1981; see also Grossman, 1984; Corbridge, 1986; Carrier and Carrier, 1989; Hill, 1986, Errington and Gewertz, 1995). Rather than a transformation of 'traditional' society occurring as previously anticipated, anthropologists (and some geographers) are beginning to recognise the robustness of indigenous economic and cultural forms, and many are beginning to recognise the dynamism and indeterminism in outcomes resulting from incorporation (e.g., Strathern, 1974; Carrier and Carrier, 1989; Connell, 1990; Kulick, 1993; Escobar, 1995; Gardner, 1995; Curry, 1997).

Currently, alternative theoretical frameworks are being explored (see Halfacree and Boyle, 1993; 1995; Fielding, 1992; Shelley and Koven, 1993; Gardner, 1995; Goss and Lindquist, 1995; Moon, 1995; McHugh and Mings, 1996), some of which are building on earlier traditions of ethnographic and biographical approaches to migration research (for a summary see Skeldon, 1995; see also Chapman and Prothero, 1985a and 1985b; Prothero and Chapman, 1985). These are paying greater attention to the role of local agency in people's capacity to interact with, and modify, the forces of global capitalism (e.g. see collection of papers in Connell, 1990; Gardner, 1995). Analyses of agency have progressed beyond simple voluntarism, as in neoclassical theory, to engage structural issues. For example, Goss and Lindquist (1995) draw on Anthony Gidden's theory of structuration to develop a theoretical framework for the analysis of Filipino international migration. Their approach attempts to reconcile functionalist and structuralist explanations of international migration to develop a concept of a migrant institution:

a migrant institution [is] a complex articulation of rules and resources which presents constraints and opportunities to individual action. Individuals act strategically within the institution to further their interests, but the capacity for such action is differentially distributed according to knowledge of rules and access to resources, which in turn may be partially determined by their position within other social institutions. ... [I]ndividuals draw selectively on institutional rules and resources in pursuit of their interests and inevitably reproduce the social system. As potential migrants, returned migrants, patrons, and institutional agents draw upon rules and resources of diverse social institutions, it is thus that their practices become institutionalized, that social networks become migrant networks and ultimately migrant institutions (Goss and Lindquist, 1995: 345). 
Goss and Lindquist illustrate how migrant institutions are reproduced and transformed by social behaviour. The theory recognises that while people are knowledgeable about their world, capable of learning and making changes, there are constraints on social life as individuals and organisations compete with each other for power and dominance (Giddens, 1984). Importantly, however, structures are not seen as immutable as in conventional structuralist approaches, but are both a medium and an outcome of social practices. This 'duality of structure' allows for both the reproduction and transformation of structures from the 'unintended consequences' resulting from the collective outcome of the actions of many individuals.

The significance of structuration theory for migration is that we can begin to see how the changed conditions resulting from incorporation are providing conditions for the creation of new and/or altered economic and social spaces, in which behaviour is both reproducing and transforming structure to produce, in the case of the Wosera, new economic and social forms that are not purely 'traditional' nor 'modern'. It is with this notion of agency in mind that we explore the ambiguity of migration in terms of the articulation of indigenous productive and social relationships with capitalist forms. ${ }^{2}$ We begin with a brief description of the Wosera sub-district and West New Britain, the migrant source and destination sites respectively. Then we outline the main characteristics of Wosera migration before examining its role in terms of how indigenous cultural, social and economic forms are changing in response to the new situations arising from incorporation.

\section{THE SETTING}

\section{The Wosera sub-district, East Sepik Province}

The migrant source area is the Wosera sub-district, an area of 800 sq. km located southwest of Maprik, East Sepik Province. Relative to other areas of Papua New Guinea, the Wosera are poor. In 1993 national per capita income was K520, and K320 for the East Sepik Province (1K = A \$1.51) (AusAID, 1995: 131, 149). Per capita income is even lower in the Wosera, and in one village was K24 in 1989 (Curry, 1992: 104). The sub-district is also one of the most densely settled rural lowland areas in Papua New Guinea, with densities ranging from 60 to 200 people per square $\mathrm{km}$ (Lea et al., 1988). These densities are very high for an economy based on swidden agriculture. In the 1960s there was mounting concern that Wosera subsistence systems were under stress and in the long-term would be unsustainable with high population growth rates (e.g., Forge, 1963; Lea, 1964). With this realisation the administration has, since the early 1960s, encouraged migration to resettlement areas both in the East Sepik Province and further afield. An important destination site for Wosera migrants has been the oil palm resettlement schemes of West New Britain (Figure 1). 


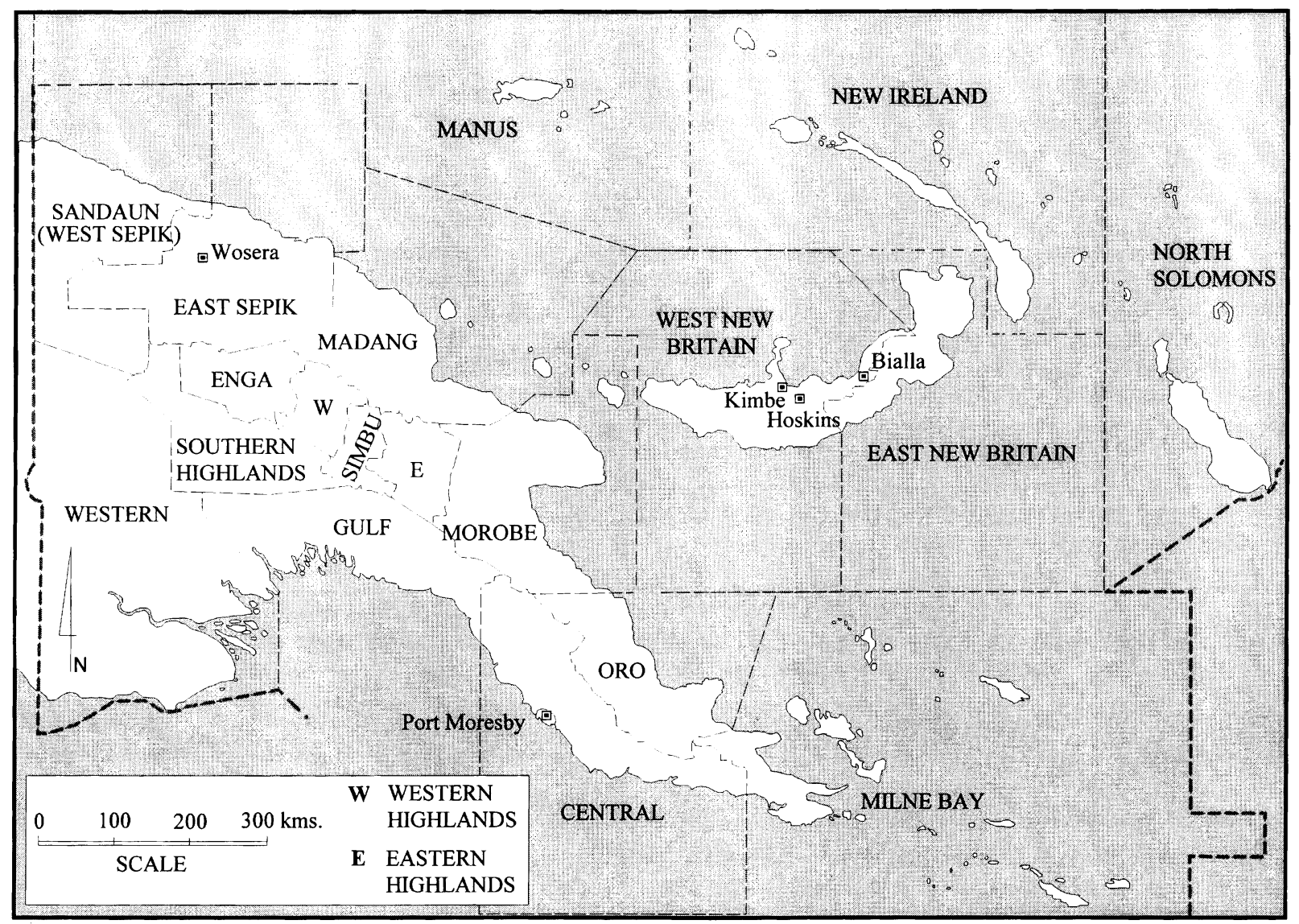




\section{Bialla Oil Palm Resettlement Scheme, West New Britain}

The Bialla Oil Palm Resettlement Scheme is located in the Ewasse District on the north coast of West New Britain, east of the provincial capital Kimbe, the fastest growing town in the country (Connell, 1997: 189). In the 1950s and 1960s, because of its sparse population, suitable climate, fertile soils and extensive forest resources, the north coast of West New Britain was considered by the Australian Administration as an ideal area for timber extraction, agricultural production and land resettlement schemes (Hulme, 1984: 235; also Hulme, 1982). PNG land resettlement schemes are government sponsored, whereby 'unused' rural land is subdivided for smallholder cash crop production (especially oil palm, coconut, rubber and cocoa). ${ }^{3}$ Over the last two decades the nucleus estate system has dominated PNG resettlement schemes, with smallholder blocks located adjacent to privately owned estate plantations (Hulme, 1984: 100). This allows smallholders access to planting material, extension services and the processing outlets provided by the estate plantations.

Since the first small-scale government sponsored land resettlement schemes were established in the late 1950s other larger scale schemes have followed throughout Papua New Guinea. Most of the large-scale land resettlement schemes, such as the Bialla Scheme, were established in the 1960s and early 1970s under the Australian colonial administration (Makara, 1976), though some schemes were implemented in the 1980s after independence. Currently, there are plans to establish large oil palm and agri-forestry resettlement schemes in West Sepik and Gulf Provinces.

The Bialla Oil Palm Scheme was established in 1972 following the perceived success of the nearby Hoskins oil palm resettlement scheme (Hulme, 1984: 253). The basic operation and structure of the Bialla scheme mirrored that of the Hoskins scheme: a joint agreement was made between the government and a private overseas company ${ }^{4}$ whereby the company agreed to develop a large nucleus estate of oil palms and a processing mill, and the government opened land adjacent to the estate for smallholder settlement. ${ }^{5}$ Oil palm planting by the indigenous population was also encouraged and this has increased steadily over the years.

Settler selection also appears to have followed that of the earlier Hoskins scheme with blocks publicly advertised and priority given to applicants from land-short areas such as Chimbu, Maprik (including the Wosera sub-district), Wabag and the Gazelle Peninsula. Many labourers involved with presettlement development or working on other resettlement schemes in the province also acquired blocks at Bialla. Presently, preference is given to indigenous Nakanai people and sons of leaseholders as blocks become available.

Most of our interview data were collected in Wilelo subdivision which is similar to other subdivisions with its own community school, aid post, OPIC office, central tradestores, churches and local market. Settler holdings are held on 99 year leases and are approximately 6 to 6.5 ha in size, of which a mean block area of 4.4 ha is planted in oil palm (data from a November 1996 OPIC 
survey). Most blockholders also maintain fairly extensive food gardens for household consumption.

According to the OPIC project manager, two of the most immediate problems facing the future of the scheme are the tensions between the indigenous Nakanai and settler population, and the absence of long term management plans for the scheme. The latter is of some immediate concern to OPIC given that the scheme is now 17 years old and at a stage where replanting is becoming necessary. Yet, little assistance or direction is provided by government. However, for migrant blockholders the most pressing threat to the future viability of the scheme is the ongoing conflict with the indigenous Nakanai. Although nearly 80 percent of Nakanai villages are now incorporated into the Bialla project, feelings of marginalisation remain, and relationships with settlers or vaira (outsiders) are tense, causing much uncertainty and insecurity among blockholders.

\section{CHARACTERISTICS OF WOSERA MIGRATION TO WNB}

A very large number of Wosera migrants are present in WNB on estate plantations, resettlement blocks, squatter settlements and on land leased or purchased from the indigenous population. Resettlement schemes and squatter settlements act as entry points for people arriving in WNB looking for work or visiting. Whilst some Wosera have settled permanently on resettlement blocks and squatter settlements, most migration from the Wosera is short-term circulation by males to find work and/or visit kin. Most young men coming to WNB for the first time plan to sign on for a three year labour contract on a plantation. Older married men tend to visit for shorter periods, typically from several months to two years, if they find work. A few migrants may stay longer than three years, but these longer stays are usually associated with a serious dispute with kin in their home village or the threat of sorcery if they return home (see below).

The large number of Wosera migrants in WNB means that extensive social networks exist for the new arrival to establish a base from which job opportunities can be identified, mainly in plantation work. The young man on his first trip away typically stays first with relatives on a block or squatter settlement. Subsequently, he may move onto a plantation and be housed in the single men's quarters. If he tires of work, the blocks and squatter settlements offer respite from plantation work while he rests and seeks alternative work. While most moves are work related, disputes also induce people to move within WNB. Thus, a visitor living for several years in WNB may make several moves during his stay, resulting in a continual flow mainly of men between the blocks, squatter settlements and plantation estates. For example, nearly all of the Wosera resettlement blocks in the Wilelo sub-division we visited, currently or very recently had visitors who were not part of the immediate family. ${ }^{6}$

Despite the frequency of Wosera migration, it still creates feelings of anxiety and sadness, especially for relatives remaining in the village. A mother often displays her grief for her departing young son by not eating for several days. 
Departing gifts like money and food are presented to migrants reaffirming social relationships, and creating debt obligations which in effect bind migrants more closely to the village socio-economy through exchange (see below and Boyd, 1990). The desire of villagers to be reunited with absent family members is expressed in several ways including maintaining the yam stocks of temporarily absent relatives (for up to 2-3 years), by leaving the sago palms of 'permanent' migrants to mature and rot, and by writing letters or sending messages with other departing villagers requesting kin to return. When questioned about unharvested sago palms in an area where sago is in short supply, Wosera villagers invariably replied that the sight of flowering and dying sago palms reminded them, and their ancestral spirits, of the absent relative. The maintenance of migrants' yam stocks for several years is believed to serve as an inducement for migrants to come home. If they fail to return within two to three years, the number of seed yams held for replanting after each harvest is allowed to decline to a minimum level necessary to maintain seed stock, but insufficient to produce a surplus for consumption. In letters to migrants, they are reminded of their yam stocks, at which stage of the planting cycle they are in, and the hard work of family members in maintaining them.

Migrants themselves also have a strong attachment to place. They consistently report strong emotional and spiritual ties with their home villages, and unusual natural events and variations in well-being are often seen as evidence of these attachments. For example, feeling unwell or lethargic is frequently interpreted by migrants as a sign that relatives at home are worrying about them, or that something is wrong at home such as an ill or dying relative. Many long-term migrants express the view that their move is not permanent despite residing in WNB for more than 20 years without ever making a trip home. Most held the view that they would go back at some stage, but were not sure when. This strong attachment to place is understandable given the spiritual significance of place. The domain of ancestral spirits (collectively called gwaleaba) is the home village consisting of the hamlets, garden land and sago groves of the patrilineage. Many migrants who die in WNB are returned to their home village for burial so that they will be among their own gwaleaba in the afterlife. The thought that on death their spirit might be separated from their ancestral complex is abhorrent to the Wosera Abelam. The few Wosera settlers at Wilelo who had buried relatives there, said they were unable to return home permanently because of the obligation to remain with the spirits of deceased relatives.

The above characteristics of Wosera migration reveal two important points. The first is the dynamic nature of migration. Wosera migration to WNB is characterised by high levels of spatial mobility both within WNB and between the Wosera and WNB. Thus, circulation is very much a part of Wosera life as there is a continual interaction through time and space between WNB and the Wosera. Secondly, migration has significant spiritual, emotional and cultural dimensions. In many ways, a migrant never really leaves the village in a spiritual and cultural sense, and hence there is no clear cut distinction between source and destination sites when examining the lived experience of Wosera migration. 


\section{THE ROLE OF MIGRATION IN CONTEMPORARY WOSERA SOCIETY}

The dynamism of migration and its spiritual, emotional and cultural dimensions brings us closer to understanding how migration has been incorporated into contemporary Wosera society. While long-distance migration for the Wosera is a recent response to capitalist penetration and incorporation, contemporary migration has certain 'pre-modern' social, cultural and economic attributes. In this section we argue that the socio-cultural and economic bases of Wosera migration remain firmly embedded within indigenous social and economic forms, rather than as an expression of 'modern' western values and notions of development. We draw upon the examples of male initiation and sorcery to illustrate the ways in which circulation and migration are influenced and informed by indigenous cultural beliefs and values. Finally, we examine the role of the indigenous exchange economy in circulation as both an enabling mechanism and a driving force as men seek to procure cash and goods for use in exchange.

\section{Circulation as a rite of passage}

For most young Wosera men the first time going overseas to WNB represents their transition to manhood. All young men aspire to leaving the village and experiencing the wider world where they will be transformed in the process to men with worldly knowledge and experience. Indeed, males who have never left the village are derided, and the disparaging term buskanaka (unsophisticated in the ways of the 'modern' world) is used to describe men who have not engaged with the 'outside world'. For the Wosera, like other peoples in PNG (e.g., Lewis, 1980), temporary migration is, in many ways, a rite of passage for young men entering adulthood. Just as traditional initiation promoted Wosera boys into the world of men, so too does migration. The parallels between traditional initiation practices and migration are striking.

Until recently, the tambaran cult (the male initiation cult) involving a series of five or six stages over a man's adult life was the principal means by which male status and masculinity was achieved. Previously young men were isolated from the rest of the village, especially women, for several months as they learned the skills and knowledge to become successful yam growers and citizens in their community. The period of separation from mother and other females was a ritual purification whereby the 'harmful' effects of close contact with females were removed, and when young boys were taught the values and beliefs of Wosera society (McGuigan, 1992). Males near the end of boyhood were placed in isolated bush shelters where they were fattened and strengthened (Forge, 1990: 21). After this period of seclusion from women and uninitiated men they would re-enter village society and were said to be unrecognisable to their mothers because they had gained so much weight.

Now when a young man reaches his mid to late teens, he often heads off in the company of older male relatives to seek work in WNB. At the time he leaves he 
is still considered to be in boyhood and the act of separation from his mother, physically and in a nurturative sense, parallels the first stage of traditional male initiation when young men move into the world of men. On his return from his first trip away he is physically and psychologically transformed. He has usually grown considerably, put on weight and his relationship with his mother is fundamentally altered in the same way as the first stage of traditional initiation. He builds his own house, his mother and others begin to treat him as an adult male rather than a child, and he is recognised as being ready for marriage. When a wife is found for him he settles down to village life until his first child is born. This marks another stage and is often the impetus for the man to leave once more on a contract away from the village. In some ways it is also like an initiation stage, but allows young married men to defer their family obligations and prolong the single life, though in a distant location and apart from the censure of village gossip and social pressures. Moreover, following the birth of a child sexual activity is proscribed until the child is weaned, usually at three years of age (Koczberski, 1989). Sexual activity between husband and wife is believed to impair the development of the child. Although these taboos are not as closely followed as before, physical removal of the husband is perceived to lessen the risk of affecting the health and development of the child in the first few critical years of life.

Not only do there appear to be parallels between the migration of young men and the early stages of the tamberan cult, but older men believe a temporary absence from the village is rejuvenating. If a man resides continuously in the village he is said to age quickly and his skin becomes 'slack'. There is some truth in this in that men recently returned from WNB do look healthier and have clear skin unlike many villagers who are underweight and have the skin disease Tinea imbricata - a disease associated with undernutrition (Gorlin, 1973). Men explain this improvement in their physical condition in terms of their separation from the deleterious effects of prolonged and sustained contact with women. Sexual intercourse and the polluting effects of close contact with women is believed to be debilitating for men, reducing their vigour and zest. Previously sexual intercourse and close contact with women was proscribed for initiates and during the yam growing season from January to June as well as when children were breastfeeding. But with the decline of these practices and taboos, men believe that their vitality is being weakened. By physically removing themselves from women they avoid the perceived debilitating effects of close contact with women and thus regain their vitality.

\section{Circulation as refuge}

Most Wosera illnesses and deaths are attributed to sorcery. If someone perceives the risk of sorcery to be high at a given time, they can remove themselves (temporarily or permanently) from these harmful elements by migrating to WNB. ${ }^{7}$ Some long-term Wosera migrants in WNB stated that they applied for a block at Bialla following sorcery attacks on themselves or close family members. Other migrants have made what they describe as 
'rescue' trips home to collect relatives suffering from sorcery-induced illnesses or to collect relatives they see as vulnerable to sorcery attack, especially children. Even those blockholders who did not leave their village specifically because of sorcery feel that WNB provides a safer environment in which to raise children. While they are not completely free from sorcery attack in WNB, the risk is perceived to be considerably less, and is probably reinforced by the fact that malaria related illnesses are much less common in WNB than in the Wosera. The constant tales of visitors to WNB claiming to be escaping village sorcery and news of village deaths or stories of migrants dying after returning to the Wosera (see Case One) perpetuate and reinforce the belief that sorcery is rife in the Wosera. Similarly, some Chambri from the Sepik River reside in the provincial town of Wewak because they are fearful of sorcery in their home villages (Gewertz and Errington, 1991; and Ward, 1980).

However, it is difficult to ascertain if someone has migrated solely because of a dispute or because of sorcery, as the two are very much interlinked. Sorcery accusations and the perceived risk of sorcery attack are heightened during disputes over land, sago, women, pigs or inter-group jealousies. Thus a person may leave the village following an unresolved dispute, a period of illness (sorcery), or the death of a relative (Cases One and Two).

\section{Case One}

A village patrilineage was reduced to a single young male a generation ago when his parents died. After being raised in his sister's household, he married and raised four sons of his own. Because the demise of his patrilineage was attributed to sorcery performed by another patrilineage of the same subclan, his sons are raising their families apart from the rest of their subclan. Also, because of their patrilineage's small size, they fear they are targets for sorcery, and believe another subclan patrilineage is eager to appropriate their garden land and sago.

During the first half of 1989, five members of the patrilineage fell ill simultaneously (symptoms of malaria and pneumonia), two of whom died. The family believed they were victims of a massive sorcery attack and isolated themselves even more from the rest of the village. All tracks into their hamlet were closed, and only close and trusted relatives were permitted entry. Their fears of sorcery were justified by the high rate of illness and death in their family, and were reinforced again in early 1990 when another family member died shortly after returning to the village following a lengthy absence in WNB.

Following this death one of the brothers, Gallus, living in WNB, returned to the village and collected his sister, his brother's son, the three young children of his recently deceased sister, and the young daughter of the recently deceased brother and took them to WNB where he believed they would be safe from sorcery. Gallus' brother remained in the village to look after their mother and the patrilineage's land and sago. When Gallus returned to WNB he applied for an oil palm block in Bialla and wrote home stating that he was not returning. However, Gallus' 
application was refused on medical grounds. While he would like to remain in WNB - he has been living there for six years now - his elderly mother has sent several messages pleading for his return.

\section{Case Two}

Peus has been to WNB several times over the last 20 years and had organised and managed a number of business ventures in his village. In 1987, he persuaded some clan members to invest in a village tradestore, and after one year the profits stood at just over K1,300. In early 1988, without consulting other store investors, Peus withdrew K700 from the store's bank account and invested it in a passenger transport business with a man from the next village. His tradestore partners started complaining bitterly, particularly Salpus, who claimed the K700 belonged to him as he had made a large initial investment in establishing the store. Salpus walked away from the business after Peus refused to refund the money.

Peus continued to run the store, but several months later four 'rascals' held up the store with shotguns taking everything including K500 in cash and some personal items belonging to Peus. Rumours spread that a local businessman (after persuasion by Salpus) organised the robbery. The businessman claimed Peus was the source of these rumours and began court proceedings against him for slander. The court required Peus to pay two large shell rings and some cash in compensation. Peus baulked at this decision claiming he could not afford such a large payout and revealed to his close associates that he was going to WNB to avoid payment.

Soon after the court case, Peus became very ill with pneumonia and immediately his family began suspecting sorcery, They traced it to the robbery when some of Peus' items were stolen. Over the next few weeks Peus' health deteriorated and eventually he was hospitalised for a week. In the meantime his family made several trips to a distant village to seek help from a man reputedly skilled in neutralising the effects of sorcery. This man, who was said to have 'cured' Peus' illness, reported that more 'poison' was still with the enemy sorcerer and therefore Peus needed to 'look after himself'. On several occasions as Peus was recovering from illness, he talked about joining his brother in WNB; the impending fine and the threat of further sorcery convinced him that going to WNB was the best solution to his predicament. In January 1990, Peus moved to WNB for five years returning only after his son went to WNB to fetch him. For most of the time he was in WNB he worked on oil palm plantations and returned home with sufficient cash to start up a store again. Since his return there has been no demand for him to pay the compensation determined previously by the court, but that may happen when his new store is established.

The two case studies illustrate not only that fear of sorcery is a prime reason for leaving the village at a given moment in time, but that the antecedents to the 
decision to migrate are usually located in a complex of factors often involving a long series of interconnected events. In Case One migration was a strategy to reduce the vulnerability of this patrilineage to sorcery. Over many years this family has had members in WNB, and for all them, migration was, and continues to be, a response to the threat of sorcery. Case Two, which is more typical of Wosera migration, reveals that a complex combination of factors are present in the decision to migrate, very few of which can be directly attributed to western concepts of market mechanisms or the compulsive forces associated with capitalist penetration. However, even in this latter case, while migration may have been an initial response to the perceived threat of sorcery, migrants do earn cash which they can subsequently invest in various business enterprises or in precapitalist exchange. It is to this latter aspect we now turn.

\section{Precapitalist exchange}

The Wosera are actively engaging with aspects of the introduced capitalist economy to reproduce their society and cultural identity. Long-distance migration and its role in indigenous exchange provides an example of this engagement, with indigenous exchange enabling and driving a high level of circulation between the Wosera and WNB. While sorcery and cultural practices such as modified initiation rituals are undoubtedly important influences on migration, the high level of circulation is contingent on the maintenance of the indigenous economy which contributes to its fluidity and flexibility. To understand this engagement, we first need to outline briefly the role of indigenous exchange in the formation of social identities, and how the indigenous exchange and market economies are articulated.

In the anthropological literature market exchange and indigenous exchange are distinguished by the terms 'commodities' and 'gifts' respectively (Gregory, 1982). Commodities are items associated with a market economy where things are produced and sold (or bartered). The parties to the transaction (buyer and seller) are independent of each other and the item exchanged is alienable in the sense that after the sale the vendor does not hold any residual rights in the item sold, and nor does the transaction alter the relationship between buyer and seller. In contrast, gift exchange is more complex in that the object exchanged is often inalienable meaning that the giver retains some residual rights in it. Also, the relationship between the parties is altered by an indigenous exchange transaction. In gift exchange the emphasis is on the social conditions about the reproduction of people - clan structure and kinship organisation. The act of gift exchange is therefore about the creation and maintenance of social relationships, not the accumulation of profits as in the market economy (Gregory, 1982: 108-109). The indigenous exchange economy thus revolves around the creation of rights in, and obligations to, people and groups, and is grounded in the system of clan-based land tenure.

In clan-based societies, individuals are located within a complex social network where the network nodes are other individuals and groups. Through exchange the social identity of an individual or group is maintained, created or 
allowed to wither vis-à-vis other individuals and groups. An adult's social identity is constructed by the network of relationships that he or she cultivates through exchange with other individuals and groups. Exchange is, in effect, the cement that binds individuals and groups into enduring relationships. Everyone's identity in Wosera society is, therefore, continually being created/modified by the exchanges in which they and members of shared networks participate. Through exchange, allegiances are formed, relative status is determined and group boundaries are given definition. Exchange is thus central to Wosera social, cultural and economic life, and ultimately related to the physical and human resources upon which individuals and groups can draw (for an example from highland PNG see Zimmer, 1990).

\section{Circulation and exchange}

With the introduction of cash cropping to the Wosera in the late 1950s and an even longer period of labour migration, the indigenous exchange economy broadened to accommodate these changes. Cash, for instance, has long been recognised as having an additional role in PNG; it serves as a medium of exchange in the market economy, and also as a gift valuable in the indigenous exchange economy, the importance of which should not be underestimated. For example, a Wosera village survey in 1989 revealed that nearly half of cash income was derived from the indigenous exchange economy (Curry, 1992), illustrating that the demand for cash is not driven purely by a profit motive nor solely by a desire for consumption in the market economy. Cash is now indispensable for fulfilling indigenous exchange obligations such as brideprices, affinal exchange, mortuary payments and the like, and circulation provides the opportunity to raise relatively large amounts of cash quickly (through earnings or through exchange from kin settled in WNB). In this way, circulation serves certain non-market and 'pre-modern' functions.

We suggest that the persistence and broadening of the indigenous exchange economy with its inclusion of 'modern' items like cash and store bought goods as gift valuables, provides two main incentives for circulation between the Wosera and WNB. First, some men migrate to procure cash and other goods for investment in the village exchange economy; and, second, village men often make the long trip to WNB for short periods in order to maintain exchange relationships with exchange partners resident in WNB. Most men who migrate to WNB return with cash and goods, much of which is disbursed through exchange on their return. For young men on their first trip away from the village, WNB offers not only a modified form of initiation into the world of men (see above), but also the opportunity to participate in exchange as adult males. Through migration boys learn their obligations in gift exchange and when they return to the village they are, for the first time, able to participate in exchange by using cash and goods obtained in WNB. One young male who recently returned to the Wosera from working in WNB invested most of his savings of K300 in exchange with kin in his home village. Another young male unable to find work in WNB was given money 
by his mother's brother so he could buy gifts to distribute through exchange on his return to the village.

The amount of cash and goods remitted to the village with returning migrants depends on a range of factors including a migrant's propensity to save and his success in finding and holding onto work. Generally, the amount remitted to the village varies with length of stay, except where short-term migrants have received cash from relatives who are long-term residents of WNB (see below). The typical short-term migrant of six months to two years stay may return with between K50 and K1,000. This may seem an insignificant amount, but in the context of Wosera incomes represents a substantial sum. However, almost all return with cash and gifts to meet exchange obligations, and compensate particular kin for looking after their family and yam gardens in their absence.

The indigenous exchange economy provides not only an incentive for circulation (to raise cash), but also a mechanism to cover migrants' labour obligations in the village (also noted in the Okapa district, Eastern Highlands Boyd, 1990: 103). Men are able to leave the village confident that male labour can be recruited through exchange to cover their household labour obligations particularly yam planting and harvesting, which are strictly male tasks. ${ }^{8}$ Labour for other major male tasks such as the felling of sago palms, cutting, clearing and fencing new gardens, and house construction, is also recruited through exchange. Women take on some male tasks when men are absent (Koczberski and Curry, 1997), but the male migrant can be assured male kin will help with yam planting and harvesting in his absence. Indigenous exchange thus facilitates migration to WNB because of the importance the Wosera Abelam place on co-operation and exchange. Gifts of labour to the family of an absent male migrant, together with unharvested sago palms and the maintenance of his yam stocks, are evidence of a migrant's continuing role in village society and lock him into further exchange obligations on his return to the village. This helps ensure a migrant's social space within the village is maintained, and, by extension, his rights to land and other resources.

Indigenous exchange also facilitates mobility by motivating people to travel to distant locations to maintain links with exchange partners residing elsewhere. Thus it is relatively easy for migrants to settle in WNB because of the support they receive from long-term migrants eager to maintain exchange relationships with the village. Indeed, visitors to WNB often arrive with little or no money and no immediate prospect of employment. Visitors' food, clothing, cash needs, and often their fares home to the Wosera, are met by their hosts who are investing in exchange relationships. It is for this reason that Wosera youth and men can remain in WNB for months at a time without any visible means of support. Cases Three and Four illustrate the role of temporary migrants in maintaining ties between long-term migrants and their home villages.

Case Three

In 1979 Pokus left his Wosera village for WNB where he held various short-term jobs until 1983. He then took a two-year contract at the Ok 
Tedi mine. He returned home to marry in 1985 and the following year moved, with his wife Mira, to WNB. In 1989 they moved into a squatter settlement with his father's younger brother. Since 1988 Pokus has been employed by a Bialla construction company.

Pokus and Mira occasionally remit money home to contribute to brideprices and mortuary payments, but most cash and gifts are presented to their continual flow of visitors from the Wosera, especially Pokus' mother's lineage. Pokus recalled the two most recent visits by his affines: in 1993 his maternal uncle was given K200 and a return boat ticket to the East Sepik, and last year he bought an air ticket to Wewak (valued at approx. K300) for his wife's father. Currently, his younger brother, Yaula, and a mother's brother's son, Tom, and his family (wife and one child) are living with him. Tom has been unemployed since 1994 and his family rely on Pokus for accommodation and sustenance.

On his most recent trip to the Wosera in 1993, Pokus returned with K400 to establish a coffee buying business. His mother's brother and father are running the business, and they also manage Pokus' village resources. Pokus maintains close ties with his village through letters. Recently his father has written to him pleading for his return as the father is old and afraid that if he dies Pokus may find it difficult to claim his agnatic rights to sago and coffee. Both Pokus' and Tom's families have plans to return home in two or three years time.

\section{Case Four}

Abraham, his wife, Jill, and five children arrived in WNB in 1979 to take up a resettlement block. Since moving to WNB they have had a continual flow of visiting relatives from home. Generally, visitors work on the block for which they are paid, and Abraham and Jill contribute to their fares home. When returning home, most visitors convey cash and goods on Abraham's behalf to his brother and other kin who are maintaining his village holdings of coffee and sago. Abraham mentioned amounts of $\mathrm{K} 600$ and $\mathrm{K} 1,000$ given to visitors and recalls giving his older brother $\mathrm{K} 1,700$ on one occasion.

Abraham occasionally makes short visits to the Wosera. His recent trips home have been related to family problems or tragedies. When in 1989 his nephew was killed in a fight in Kimbe, Abraham took the body home for burial. Earlier visits home in the eighties were at the request of his elderly father. His father, afraid of being ensorcelled, asked Abraham to bring him to WNB where he would be safe. After spending some time on the block, his father requested Abraham to take him home. Later his father wrote again concerned that he might die before seeing Abraham again, so Abraham made another trip home and brought his father and older brother to WNB. His father died at WNB and is buried at Wilelo.

Currently, eight members of Abraham's mother's natal lineage are residing on the block including his mother's brother, Jacob. Jacob has 
visited Abraham on several occasions. He first visited as a young single man and then returned home to marry. In 1988, after his second son was born, Jacob returned to live with Abraham and worked for three years on an oil palm plantation before returning to the Wosera. In August 1994, following a dispute in the village, he returned to Abraham's block with his father, wife and four children. Jacob finds occasional work, but his family relies mostly on Abraham for support. He plans to purchase an oil palm block.

Abraham and Jill have no plans to return permanently to the village, particularly as Abraham's father is buried at Wilelo. However, they said that over the next few years their sons will be sent home on visits so they can be shown their patrilineage's holdings of sago and coffee and learn from Abraham's brother the history of the patrilineage and its place in the subclan. This knowledge is necessary for substantiating resource claims, and would be crucial if Abraham's remaining brother in the village died and the sons needed to prove their resource claim.

\section{Long-term migrants and exchange}

Long-term migrants therefore make substantial investments in exchange by hosting visitors from home. While it appears that long-term migrants do not remit cash to village kin directly through bank drafts or postal orders, they can invest substantial amounts of cash and goods in the stream of short-term visitors from the Wosera. This can be an expensive undertaking especially when visitors time their stay to coincide with unusually high exchange demands in the village such as the raising of brideprices, large compensation demands and mortuary payments. In these instances, contributions by the longterm migrant towards indigenous exchange in the village can be significant.

The level of support (gifts of clothing, cash and fares home) accorded visitors varies greatly depending on their contribution to work on the block and, importantly, on the nature and type of exchange relationship between the visitor and blockholder. For example, an in-law such as a wife's father or brother, can anticipate above normal levels of remuneration for labour, which is consistent with affinal exchange obligations. In one instance, a blockholder gave his visiting father-in-law K900 and an airline ticket home. This greatly exceeded the value of his father-in-law's labour contribution while visiting, but was entirely consistent with this type of exchange relationship. Therefore, payments to short-term visitors do not represent entirely the commodification of social relationships, but rather the values and standards of the indigenous exchange economy.

Demands on long-term migrants, particularly blockholders, may appear excessive, but it is in their interest to maintain exchange relationships with kin so that their social identity in the village, and hence their claim to village resources, remains intact (see Connell, 1997: 184-185). As indicated above, most long-term migrants believe they will return home permanently at some 
point, so the maintenance of exchange relationships keeps this option open. Indeed, many long-term migrants initiate circulation by writing letters home requesting kin to visit them. Of the very few Wosera blockholders interviewed who had not maintained exchange relationships with their home villages, all recognised that their sons had lost any claims to village land and sago. By maintaining exchange relationships, long-term migrants assert a presence and influence on village affairs and, because they are generally wealthier than villagers, their ability to participate in exchange at higher levels tends to raise their status and give them prestige. Long-term migrants are sometimes the largest individual investors in village businesses, and some pay the school fees of their relatives' children and contribute generously to brideprices and mortuary payments. Their achievements in exchange mean that many Wosera blockholders in WNB, despite being leaseholders for 17 years, still have relatives looking after their village holdings of land, coffee and sago. Their success in maintaining these strong exchange relationships with their home villages is reflected in the statements of their Wosera relatives who sometimes refer to them as if they have the status of resident lineage heads.

While exchange relationships with the village are usually maintained through short-term visitors from the Wosera, many long-term migrants make occasional trips home (Cases Three and Four). These trips are primarily for social and family reasons, but many long-term migrants see them as an opportunity to reinforce their claim to village resources, and as a deterrent to other village lineages considering appropriating their land and sago. On these trips home, the social identity and claim to resources of long-term migrants is boosted through their physical presence and reinforced by the cash and other gifts they invest in exchange. Also, many blockholders now send their eldest sons home to learn their clan stories and to be shown the boundaries of their patrilineal and subclan resources such as land, sago and permanent cash crops. Some also send their young sons, and occasionally daughters, home to marry.

In summary, it is evident that the indigenous exchange economy plays a fundamental role in shaping migration patterns between the Wosera and WNB. This operates in two ways. Firstly, the incorporation of cash and 'modern' goods as gift valuables provides an incentive for people to migrate to raise cash to invest in exchange; and, secondly, it is an enabling mechanism which facilitates the movement of people by covering labour shortfalls in the village and making it easier for people to settle in WNB.

These migration strategies appear to reinforce Curtain's (1981) notion of the 'straddled' peasant household under the dual dependence modes of production approach (Burawoy, 1976). Up to a point this is correct in that village households are pursuing strategies where some members remain in subsistence production while others engage in labour migration to support the household. However, the emphasis on labour migration ignores circulation for other reasons such as to escape village conflict and/or sorcery, and it devalues indigenous exchange transactions and relationships which are so important in Wosera society for the maintenance and creation of individual and group social identity. 


\section{CONCLUSION}

This paper has presented evidence to suggest that migration for the Wosera has been adopted as a modified form of initiation for young men, as a refuge from sorcery, as a break from the routine of village life, and to achieve socioeconomic and cultural goals that are firmly rooted in the indigenous exchange economy. It seems that the Wosera are willing to embrace those aspects of the 'modern' economy that further their own indigenously defined goals and objectives. We could not say that the high level of Wosera circulation is indicative of a transition to a market economy, nor could we say that the capitalist economy is undermining 'traditional' interests, values and economic structures. Long-distance migration is now an integral part of the social and cultural fabric of Wosera life. Indeed, as the paper suggests, the destination site of migrants is in many ways an extension of village social and cultural life.

The research reveals that conventional models of migration using either functionalist or structuralist interpretations provide an insufficient explanation for Wosera migration. Both frameworks largely ignore or underestimate the significance of the indigenous economy; the former by assuming it away (Gregory, 1982: 108-109; Mehmet, 1995); the latter by portraying it as an emasculated version of its pre-incorporated state - passive and dependent, a mere puppet of global capitalism. Moreover, both frameworks fail to recognise adequately how the indigenous socio-economy both structures and is structured by migration behaviour to such an extent that migration and circulation have now become, for the Wosera Abelam, a 'way of life' underpinned by indigenous values and meanings. This is not to deny the role of uneven spatial development and land shortages, for example, but to highlight how indigenous socio-economic structures shape - and are in turn shaped by - the 'modern' phenomenon of long-distance migration.

Thus the ostensibly 'modern' phenomenon of migration has been recast and imbued with indigenous values and meanings that contain 'pre-modern' and non-market elements. New socio-economic structures are emerging that draw simultaneously on both indigenous and introduced socio-economic elements for their form and meaning. While capitalism has created new conditions for long-distance movement (initially through the Migrant Labour Scheme - see Curtain, 1981 and later through government policies of resettlement), these incipient social networks have, over time, become 'sedimented' as an integral part of the Wosera socio-economy. Instead of a transformation of Wosera society resulting from this encounter with global capitalism, a 'hybrid' socioeconomy is emerging that contains elements of both economic and social forms (see Curry, 1992: 6-17, 251). As Gregory (1982: 116) notes:

The essence of the PNG economy today is ambiguity. A thing is now a gift, now a commodity, depending on the social context of the transaction.... The colonisation of PNG has not produced a one-way transformation from 'traditional goods' to 'modern goods', but complicated a situation where things assume different social forms at different times and in different places. 
Like cash and other 'modern' items and behaviour, migration has assumed certain non-market and 'pre-modern' cultural and ritual attributes. Other writers, mainly anthropologists, have begun to document the interactions between the 'modern' and indigenous sectors, particularly with regards to how cash has been incorporated into indigenous social and political systems (e.g., Gregory, 1980; Boyd, 1985; Sexton, 1986; Clark, 1989; Maclean, 1989; Nihill, 1989; see also Healey, 1985; 1989b; Feil, 1987: 285). In a striking example from the eastern highlands, Boyd (1985: 325) documented how traditional pig festivals have been transformed by the 'commercialisation of ritual' into 'singsing bibnis', in which elements of traditional gift exchange occur at the same time as 'profits are being accumulated by the unencumbered sale of commodities.' Cash, beer and pork are transacted as both gifts and commodities, with profits channelled into both capital investment and indigenous exchanges such as brideprices. As Gregory (1982) has noted: '... the whole economy is 'modern'. The gift exchange practised in PNG today is not a pre-colonial relic but a contemporary response to contemporary conditions.' (1982: 115).

Similarly, in a study of PNG criminal behaviour, Goddard (1995) likened 'rascals' to bigmen in a crime-fed gift economy in which the proceeds of crime are rapidly dispersed through gift exchange. While 'rascalism' is perhaps an extreme example of the recasting of a 'modern' behaviour (crime) through the appropriation of commodities as gifts in indigenous exchange, there are parallels with migration behaviour. Both crime and long-distance migration superficially appear (from a Eurocentric perspective) to be 'modern' phenomena resulting from the capitalist encounter: the former a negative outcome of poverty, unemployment and alienation; the latter, a response to compulsive economic forces or the outcome of economically rational utility-maximising behaviour . These offer only partial explanations, because they deny the continued significance of indigenous socio-economic structures and values in modified form following capitalist penetration, and fail to recognise the emerging syncretism of 'pre-modern' and 'modern' forms of behaviour and values.

Finally, it must be stressed that the indigenous socio-economy is not static and unresponsive to change, and nor is it a vestige of its precolonial status; rather, the contemporary Wosera socio-economy is a vibrant blend of 'modern' and 'pre-modern', of capitalist and precapitalist phenomena, where the boundaries are continually shifting and indistinct. The challenge, therefore, is to recognise the dynamism and indeterminism of this capitalist-precapitalist encounter, for insights into these processes can help broaden our understanding of not only migration, but the whole gamut of social and economic change commonly associated with 'development'.

\section{ACKNOWLEDGEMENTS}

The authors thank Associate Professor John Connell for his very helpful comments on an earlier version of this paper. Any errors of interpretation, of course, remain our own. We are indebted to many people for assistance and 
hospitality during fieldwork. In particular we thank OPIC staff and leaseholders in WNB, especially villagers from the Wosera sub-district, ESP who generously gave their time and assistance. Fieldwork in 1995/96 was partly funded by an ARC Small Grant from Curtin University.

\section{NOTES}

1 The terms 'precapitalist economy' and 'indigenous economy' are used synonomously here. While we prefer the latter term, because of the former's connotations of evolutionary development, 'precapitalism' is used occasionally in reference to the existing literature.

2 The case study material is drawn from fieldwork in December 1995 and January 1996 in WNB and the Wosera, and from Wosera fieldwork in 1988 and 1989.

3 There are instances, however, of land being made available for subsistence production for people from land-short areas (e.g., The Gavien Resettlement Scheme, East Sepik Province).

4 Currently the joint partner with the government is a Malaysian owned company, Hargy Oil Pty Limited.

5 When the Bialla leaseholders first settled their blocks, they were provided with a basic two-room house (or house-building material), a water tank, tools (e.g., axes for forest clearing), oil palm seedlings and a small fortnightly allowance. These were financed by a loan from the Papua New Guinea Development Bank with repayment beginning after the first harvest. Most people we interviewed completed their loan repayments within 10 years, many within six years.

6 A November 1995 OPIC survey revealed that 68 percent of blocks in the Wilelo subdivision had visitors $(\mathrm{N}=288)$.

7 For sorcery to be performed, sorcerers must be supplied with personal items ('dirty' M.P.) that have been in close physical contact with the intended victim such as food scraps, bodily excretions, hair and bits of clothing. Why physical removal of victims or potential victims to WNB is effective against sorcery is unclear, but may be related to the removal of the victim as a 'problem' from village society. That is, the motivation to harm someone through sorcery may be lessened when the 'problem' individual is absent from the village.

8 The Wosera have strict cultural codes that identify yam planting and harvesting as male tasks, and such codes are sanctioned by beliefs that female involvement in these stages of the yam cycle is inimical to yam growth and yields.

Recruitment of labour through exchange is not so important for younger men who have yet to marry and establish their own yam gardens, but it is vitally important for older men with dependent families.

\section{REFERENCES}

AIDAB (1994) Papua New Guinea: the role of government in economic development International Development Issues No 33 Canberra: National Capital Printing.

Amin, S. (ed) (1974) Modern Migrations in Western Africa London: Oxford University Press for the International African Institute.

AusAID (1995) Papua New Guinea: improving the investment climate International Development Issues No. 39 Canberra: Anutech Pty Ltd.

Boyd, D.J. (1985) The commercialisation of ritual in the Eastern Highlands of Papua New Guinea Man 20: 325-340.

Boyd, D.J. (1990) New wealth and old power: circulation, remittances, and the control of inequality in an Eastern Highlands community, Papua New Guinea. In J. Connell (ed) Migration and Development in the South Pacific Pacific Research Monograph No. 24, National Centre for Development Studies, Australian National University pp. 97-106.

Burawoy, M. (1976) The functions and reproduction of migrant labour: comparative material 
from southern Africa and the United States American Journal of Sociology 81(5): 10501080.

Carrier, J.G. and Carrier, A.H. (1989) Wage, Trade, and Exchange in Melanesia. A Manus Society in the Modern State Berkeley, California: University of California Press.

Chapman, M. and Prothero, R.M. (1985a) Circulation between 'home' and other places: some propositions. In M. Chapman and R.M. Prothero (eds) Circulation in population Movements: substance and concepts from the Melanesian case London: Routledge and Kegan Paul pp. 1-12.

Chapman, M. and Prothero, R.M. (eds) (1985b) Circulation in Population Movements: substance and concepts from the Melanesian case London: Routledge and Kegan Paul.

Clark, J.L. (1989) The incredible shrinking men: male ideology and development in a southern highlands society Canberra Anthropology 12(1\&2): 120-143. Special Volume - Culture and Development in Papua New Guinea.

Connell, J. (ed) (1990) Migration and Development in the South Pacific Pacific Research Monograph No. 24, National Centre for Development Studies, Australian National University.

Connell, J. (1997) Papua New Guinea: The Struggle for Development London: Routledge.

Corbridge, S. (1986) Capitalist World Development. A Critique of Radical Development Geography London: Macmillan Education Ltd.

Curry, G.N. (1992) Kin and Kina: A Study of Emerging Inequalities in a Rural Lowland Society in Papua New Guinea Unpublished PhD thesis, University of New England.

Curry, G.N. (1997) Warfare, social organisation and resource access amongst the Wosera Abelam of Papua New Guinea Oceania 67(3): 194-217.

Curtain, R.L. (1981) Migration in Papua New Guinea: the role of the peasant household in a strategy of survival. In G.W. Jones and H.V. Richter (eds) Population Mobility and Development: Southeast Asia and the Pacific Development Studies Centre, Australian National University: Development Studies Centre Monograph No. 27 pp. 187-204.

Epstein, T.S. (1968) Capitalism, Primitive and Modern: Some Aspects of Tolai Economic Growth Canberra: Australian National University Press.

Errington, F.K. and Gewertz, D.B. (1995) Articulating Change in the 'Last Unknown' Boulder: Westview Press.

Escobar, A. 1995 Encountering Development: The Making and Unmaking of the Third World New Jersey: Princeton University Press.

Feil, D.K. (1987) The Evolution of Highland Papua New Guinea Societies Cambridge: Cambridge University Press.

Fielding, A. (1992) Migration and culture. In Champion and Fielding (eds) Migration processes and patterns, Vol 1, research progress and prospects London: Bellhaven pp. 201-212.

Finney, B.R. (1973) Big Men and Business: Entrepreneurialship and Economic Growth in the New Guinea Highlands Hawaii: University of Hawaii.

Fitzpatrick, P. (1980) Law and State in Papua New Guinea London: Academic Press.

Forge, A. (1963) The Wosera, its present position and problems. Report to the ADO, Maprik. January, 1963. Mimeo.

Forge, A. (1990) The power of culture or vice-versa. In N. Lutkehaus, C. Kaufmann, W.E. Mitchell, D. Newton, L. Osmundsen and M. Schuster (eds) Sepik Heritage: Tradition and Change in Papua New Guinea North Carolina: Carolina Academic Press pp. 160-170.

Gardner, K. (1995) Global Migrants, Local Lives: Travel and Transformation in Rural Bangladesh Oxford: Clarendon Press.

Gewertz, D.B. and Errington, F.K. (1991) Twisted Histories, Altered Contexts: Representing the Chambri in a World System Cambridge: Cambridge University Press.

Giddens, A. (1984) The Constitution of Society: Outline of the Theory of Structuration Cambridge: Polity Press.

Goddard, M. (1995) The rascal road: crime, prestige and development in Papua New Guinea The Contemporary Pacific 7(1): 55-80.

Gorlin, P. (1973) Health, wealth, and agnation among the Abelam: the beginnings of social 
stratification in New Guinea Unpublished PhD thesis, Columbia University.

Goss, J. and Lindquist, B. (1995) Conceptualizing international labor migration: a structuration perspective International Migration Review 29(2): 317-351.

Gregory, C.A. (1980) Gifts to men and gifts to God: gift exchange and capital accumulation in contemporary Papua Man 15(4): 626-652.

Gregory, C.A. (1982) Gifts and Commodities London: Academic Press.

Grossman, L. (1984) Peasants, Subsistence Ecology, and Development in the Highlands of Papua New Guinea New Jersey: Princeton University Press.

Halfacree, K.H. and Boyle, P.J. (1993) The challenge facing migration research: the case for a biographical approach Progress in Human Geography 17(3): 333-348.

Halfacree, K.H. and Boyle, P.J. (1995) 'A little learning is a dangerous thing': a reply to Ron Skeldon Progress in Human Geography 19(1): 97-99.

Healey, C.J. (1985) New Guinea inland trade: transformation and resilience in the contact of capitalist penetration Mankind 15(2): 127-144.

Healey, C.J. (1989) Trade, marriage and unequal exchange in the Papua New Guinea Highlands Canberra Anthropology 12(1\&2): 48-73. Special Volume - Culture and Development in Papua New Guinea.

Hill, P. (1986) Development Economics on Trial. The Anthropological Case for the Prosecution Cambridge: Cambridge University Press.

Hirst, J., Overton, J., Allen, B. and Byron, Y. (eds) (1988) Small-Scale Agriculture Canberra: Commonwealth Geographical Bureau and Department of Human Geography, Research School of Pacific Studies, Australian National University.

Hulme, D. (1982) Land settlement schemes in Papua New Guinea: an overview Land Reform 1: $21-42$.

Hulme, D. (1984) Land settlement schemes and rural development in Papua New Guinea Unpublished $\mathrm{PhD}$ thesis, James Cook University.

Jones, G.W. and Richter, H.V. (eds) (1981) Population Mobility and Development: Southeast Asia and the Pacific Development Studies Centre, Australian National University: Development Studies Centre Monograph No. 27.

Koczberski, G. (1989) Child nurturing practices in the Wosera area of the East Sepik Province, Papua New Guinea: implications for the nutritional status of young children Unpublished BA (Hons) thesis, University of New England.

Koczberski, G. and Curry, G.N. (1997) Women and migration: a case study from a lowlands village in Papua New Guinea. In J. Fairhurst, I. Booysen and P. Hattingh (eds) Migration and Gender: Place, Time and People Specific International Geographical Union on Gender and Geography, and Population Geography South Africa: University of Pretoria Press pp. $183-198$.

Kulick, D. (1993) Heroes from Hell: representations of 'rascals' in a Papua New Guinean village Anthropology Today 9(3): 9-14.

Lea, D.A.M. (1964) Abelam Land and Sustenance. Swidden Horticulture in an Area of High Population Density, Maprik, New Guinea Unpublished PhD thesis, Australian National University.

Lea, D.A.M., Joel, N. and Curry, G. (1988) A Maprik journey: backwards and forwards in time? Cash cropping among the Abelam. In J. Hirst, J. Overton, B. Allen and Y. Byron (eds) Small-Scale Agriculture Canberra: Commonwealth Geographical Bureau and Department of Human Geography, Research School of Pacific Studies, Australian National University.

Lewis, G. (1980) Day of Shining Red Cambridge: Cambridge University Press.

Lutkehaus, N., Kaufmann, C., Mitchell, W.E., Newton, D., Osmundsen, L. and Schuster, M. (eds) (1990) Sepik Heritage: Tradition and Change in Papua New Guinea North Carolina: Carolina Academic Press.

Maclean, N.A. (1989) The commoditization of food: an analysis of a Maring market Canberra Anthropology 12(1\&2): 74-98. Special Volume - Culture and Development in Papua New Guinea.

Makara, L. (1976) West New Britain Province Harvest 3(4): 140-148. 
Massey, D.S., Arango, J., Hugo, G., Kouaouci, A., Pellegrino, A. and Taylor, J.D. (1993) Theories of international migration: a review and appraisal Population and Development Review 19(3): 431-466.

McGuigan, N.D. (1992) The social context of Abelam art: a comparison of art, religion and leadership in two Abelam communities Unpublished $\mathrm{PhD}$ thesis, University of Ulster.

McHugh, K.E. and Mings, R.C. (1996) The circle of migration: attachment to place in aging Annals of the Association of American Geographers 86(3): 530-550.

Mehmet, O. (1995) Westernizing the Third World: the Eurocentricity of economic development theories London: Routledge.

Meillassoux, C. (1981) Maidens, Meal and Money Cambridge: Cambridge University Press.

Moon, B. (1995) Paradigms in migration research: exploring 'moorings' as a schema Progress in Human Geography 19(4): 504-524.

Nihill, M. (1989) The new pearlshell: aspects of money and meaning in Anganen exchange Canberra Anthropology 12(1\&2): 144-161. Special Volume - Culture and Development in Papua New Guinea.

PNGIMR. (1986) A Rapid Rural Appraisal of Agriculture, Nutrition and Health in the Wosera Sub-district, East Sepik Province Papua New Guinea Institute of Medical Research.

Prothero, R.M. and Chapman, M. (eds) (1985) Circulation in Third World Countries London: Routledge and Kegan Paul.

Rowley, C.D. (1965) The New Guinea Villager: a retrospect from 1964 London: Cheshire.

Sexton, L.D. (1986) Mothers of Money, Daughters of Coffee: The Wok Meri Movement Michigan: UMI Research Press.

Shelley, I.I. and Koven, S.G. (1993) Interstate migration: a test of competing interpretations Policy Studies Journal 21: 243-261.

Skeldon, R. (1995) The challenge facing migration research: a case for greater awareness Progress in Human Geography 19(1): 91-96.

Stark, O. and Bloom, D.E. (1985) The new economics of labor migration American Economic Review 75: 173-178.

Strathern, A.J. (1974) Anthropology and problems of social change in Papua New Guinea Inaugural lecture, University of Papua New Guinea.

Wallerstein, I. (1974) The Modern World System, Capitalist Agriculture and the Origins of the European World Economy in the Sixteenth Century New York: Academic Press.

Ward, R.G. (1980) Migration, myth and magic in Papua New Guinea Australian Geographical Studies 18(2): 119-134.

Wolpe, H. (1972) Capitalism and cheap labour-power in South Africa: from segregation to apartheid Economy and Society 1(4): 425-455.

Wolpe, H. (ed) (1980) The Articulation of Modes of Production London: Routledge and Kegan Paul.

Zimmer, L.J. (1990) When tomorrow comes: future opportunities and current investment patterns in an area of high out-migration. In J. Connell (ed) Migration and Development in the South Pacific Pacific Research Monograph No. 24, National Centre for Development Studies, Australian National University pp. 82-96. 